\title{
Evaluation of surgical treatment outcomes in patients with laryngeal cancer during a 5-year follow-up
}

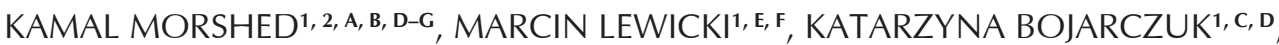 \\ AGNIESZKA TARASIUK-STANIAK ${ }^{2, \text { B }}$, AGATA SMOLEŃ1, A, C-F
}

'Chair and Department of Epidemiology and Clinical Research Methodology, Medical University of Lublin ${ }^{2}$ Department of Otolaryngology and Oncology, County Hospital in Poniatowa

A - Study Design, B - Data Collection, C - Statistical Analysis, D - Data Interpretation, E - Manuscript Preparation, $\mathbf{F}$ - Literature Search, $\mathbf{G}$ - Funds Collection

Summary Background. Recurrences are the main cause of failure in the treatment of laryngeal cancer. The outcome depends both on the success of treatment of the primary tumour and the procedure used to treat the recurrence.

Objectives. Evaluation of the incidence of recurrences in patients treated surgically for laryngeal cancer during a 5-year follow-up. Material and methods. The study group consisted of 123 patients treated for laryngeal squamous cell carcinoma. Surgical treatment was used in all patients. Total laryngectomy was conducted in $85(69.1 \%)$ patients, while endoscopic laser resection of the tumour was conducted in $38(30.9 \%)$ patients.

Results. Local recurrence occurred in $15(12.2 \%)$ patients, lymph node recurrence occurred in $10(8.1 \%)$ patients, and local and lymph node recurrence occurred in $8(6.5 \%)$ patients. In total, recurrences occurred in $33(26.8 \%)$ patients, and distant metastases occurred in $15(12.2 \%)$ patients. The incidence of recurrences during the 5 -year follow-up increased significantly with the increase of the T feature $(p=0.02), N$ feature $(p=0.01)$, stage of clinical progression $(p=0.003)$, and histological malignancy $G$ stage $(p=0.002)$. The incidence of recurrences also depended on the origin of the cancer. In the glottic area, recurrences were significantly less frequent than in the epiglottic area $(p=0.009)$. Multiple factor analysis revealed that the presence of recurrences $(p<0.00001)$ was an important independent prognostic factor in the investigated group of patients with laryngeal cancer during the follow-up.

Conclusions. Recurrences most often occur in patients with an epiglottic tumour at stages T3 and T4 of local progression, patients with metastases to lymph nodes, patients at stages III and IV of clinical progression, and patients with poorly differentiated squamous cell carcinoma (G3). Patients with local recurrences have a significantly worse prognosis than those without recurrences. The presence of recurrences is an important independent prognostic factor.

Key words: laryngeal cancer, surgical treatment, 5-year follow-up.

Fam Med Prim Care Rev 2016; 18(3): 302-307

\section{Background}

Malignancies constitute as much as $90 \%$ of the cases of head and neck cancer. Among the most common malignancies in this area are squamous cell carcinoma (75\%), lymphomas $(2.5 \%)$, and salivary gland cancer $(7.5 \%)$. Other malignancies constitute $15 \%$ of cases. Squamous cell carcinoma is the most frequent laryngeal malignancy, occurring in $98.7 \%$ of cases [1]. It develops from squamous cell epithelium or pseudostratified ciliated epithelium that transforms into stratified squamous epithelium via metaplasia.

A retrospective analysis of selected epidemic and clinical phenomena regarding laryngeal and hypopharyngeal cancers, conducted between 1991 and 2001 in 19 clinical centres in Poland and including 11,884 cases of laryngeal malignancies, revealed that the proportion of women with laryngeal and hypopharyngeal cancers increased significantly in the period 1991-2001. The M:F proportion is $8: 1$. The peak incidence in both sexes fell in the age range 51-60 years. The prevalent location of laryngeal cancer in the analyzed period was the glottis $(47.6 \%)$, followed by the epiglottis $(40 \%)$. In the majority of patients $(59.7 \%)$, laryngeal and hypopharyngeal cancer was diagnosed at late stages of local progression (T3 and T4) and depended on the status of the regional lymph nodes of the neck ( $\mathrm{N}$ feature) [1].

The oncogenesis of head and neck cancer is presumed to be a multi-step process with the involvement of both ex- ogenous and endogenous carcinogenic factors. The former include physical, chemical and biological factors, while the latter include genetic factors, impairment of the immune system and hormonal disorders. The exogenous factors impair cell proliferation and generate mutations in the genetic apparatus of the cell (e.g. mutations in tumour suppressor genes, oncogenes and modulatory genes). Among the known risk factors of head and neck cancer are cigarette smoking and alcohol, particularly spirits, which are considered to be the main factors causing over $90 \%$ of cases of the development and incidence of laryngeal cancer $[2,3]$.

The effectiveness of oncological treatment based on the 5 -year survival of patients without clinical signs of recurrence is poor as the 5 -year survival rate in patients with $\mathrm{T} 1$ and T2 tongue cancer is approximately $28 \%$. In patients with $\mathrm{T} 1$ and $\mathrm{T} 2$ tonsil cancers, the treatment outcome is better, and the 5 -year survival rate is approximately $37 \%$. However, in the case of clinical progression stages III and IV, no cases of 5-year survival were observed [4].

\section{Objectives}

The aim of the study was an evaluation of the incidence of recurrences in patients treated surgically for laryngeal cancer during a 5-year follow-up. 


\section{Material and methods}

The study group consisted of 123 patients with laryngeal cancer who had not been previously undergoing chemotherapy and/or radiation therapy. Histopathological examination revealed squamous cell carcinoma in all patients, and was followed by the assessment of histological malignancy grade ( $\mathrm{G}$ feature).

The data characterizing the epidemiology and clinical status of the tumour obtained from medical history were analyzed for: 1) sex and age; 2) addictions - cigarettes and alcohol; 3) location of the tumour in the larynx; 4) TNM classification and stage of clinical progression; 5) histological malignancy grade ( $G$ feature); 6) methods of treatment; and 7) recurrences and deaths. Information on health status was obtained from medical records provided by the patients or their families. The five-year survival rate with and without recurrences was evaluated.

The TNM classification and stage of clinical progression of the tumour were established in accordance with the Union for International Cancer Control (UICC) guidelines [5].

The WHO Histological Typing of Tumours of the Upper Respiratory Tract and Ear (WHO, Geneva 1978) determines the grade of malignancy of squamous cell carcinomas based on the maturity characteristics of their cells. A 4-degree grading was established based on the degree of cell maturity: highly mature, well differentiated (G1), moderately mature, moderately differentiated (G2), of low maturity, poorly differentiated (G3) and undifferentiated (G4), rarely diagnosed in the laryngeal mucosa [6].

\section{Statistical analysis}

The results of the study were analyzed statistically. The values of the analyzed parameters measured on a nominal or ordinal scale were characterized using amount and percentage; those measured on an interval scale were characterized using the arithmetic mean, standard deviation, median and range of variability depending on the form of distribution (Shapiro-Wilk test). An $\chi^{2}$ test for independence was used to establish correlations between the analyzed characteristics, with Yates' correction used in the case of small sample sizes. To analyze and compare the survival rates after treatment, survival analysis was used during the follow-up. Survival function was estimated using the Kaplan-Meier estimator based on continuous survival times. The analysis of subgroups conducted according to the categories of the analyzed qualitative characteristics required tests for the comparison of survival in two or more subgroups: log-rank test or Cox's F test. To assess the impact of ordinal or continuous quantitative variables, Cox's proportional hazards model was used.

A $5 \%$ error and the significance level of $p<0.05$ were established to indicate the statistical significance of the obtained differences or correlations. The statistical analyses were conducted using Statistica v. 10.0 software (StatSoft, Poland).

\section{Results}

Surgical treatment was used in all 123 patients. Total laryngectomy was conducted in 85 (69.1\%) patients, while endoscopic laser resection of the tumour was conducted in $38(30.9 \%)$ patients. The investigated group consisted of 108 $(87.8 \%)$ men and $15(12.2 \%)$ women. The age of the patients ranged from 32 to 78 years (mean 58.6 \pm 9.1 years). The prevalent stages of local progression were T3 (45 cases) and T4 (40 cases). The tumour invaded the epiglottis in 59 patients, the glottis in 60 patients, and the hypoglottic region in 4 patients.

In the group of 85 patients subjected to total laryngectomy, stage IV of the clinical progression of laryngeal cancer was found in 60 patients, and stage III was found in 25 patients.

In the group of 38 patients in whom endoscopic laser resection of the tumour was conducted, the local progression stages T1 and T2 were found in 24 and 14 patients, respectively. In this group of patients, stage I of clinical progression was observed in 24 out of 41 patients, stage II was observed in 12 patients, while stage III was observed in 2 patients.

Well differentiated tumour (G1) was found in 35 cases, moderately differentiated tumour (G2) was found in 73 cases, and poorly differentiated tumour (G3) was found in 15 cases.

Lymph nodes were assessed using palpation and ultrasound (US) examination of the neck before the surgery. Enlargement of lymph nodes $(\mathrm{N} 1+2+3)$ was reported in 45 patients.

The 5-year post-treatment follow-up was survived by 72 $(58.5 \%)$ patients, while $51(41.5 \%)$ patients died, including $34(27.6 \%)$ due to cancer and $17(13.8 \%)$ from other causes. Local recurrence occurred in $15(12.2 \%)$ patients, lymph node recurrence occurred in $10(8.1 \%)$ patients, while local and lymph node recurrence and/or distant metastases occurred in $8(6.5 \%)$ patients. Distant metastases occurred in $15(12.2 \%)$ patients, including lung metastases in 12 patients, liver metastases in 1 patient, spinal cord metastases in 1 patient, and metastases in multiple locations in 1 patient. In total, recurrences were observed in 33 (26.8\%) patients, and no recurrence was observed in $90(73.2 \%)$ patients (Tab. 2).

During the 5-year follow-up, lymph node recurrences were found in $10(8.1 \%)$ patients in the period between 3 and 48 months after treatment, with a mean value of 18.4 months.

Local and lymph node recurrences were found in 8 $(6.5 \%)$ patients. Radical surgery of the recurring tumour was conducted in 5 patients, and palliative care due to the size of the recurrence was provided to the remaining 3 patients. Local and lymph node recurrences occurred between 3 and 48 months (mean 18.4 months) after the original surgery in the patients included in the 5-year follow-up. Distant metastases occurred in $12.2 \%$ of the patients included in the 5 -year follow-up, with the mean time of occurrence of metastases of 23.3 months (Tab. 1).

\begin{tabular}{|c|c|c|c|c|c|c|}
\hline \multirow{2}{*}{$\begin{array}{l}\text { Type of failure } \\
\text { Local recurrence }\end{array}$} & \multirow{2}{*}{$\begin{array}{l}\begin{array}{l}\text { Number of } \\
\text { patients }(n)\end{array} \\
15\end{array}$} & \multirow{2}{*}{$\begin{array}{l}\% \text { of all } 123 \\
\text { treated patients } \\
12.2\end{array}$} & \multirow{2}{*}{$\begin{array}{l}\% \text { of all failures } \\
31.25\end{array}$} & \multicolumn{2}{|c|}{$\begin{array}{l}\text { Mean time of occurrence } \\
\text { (months) }\end{array}$} & \multirow{2}{*}{$\begin{array}{l}\text { Range } \\
\text { in months } \\
2-24\end{array}$} \\
\hline & & & & 7.5 & $M e^{*}=6$ & \\
\hline Lymph node recurrence & 10 & 8.1 & 20.8 & 18.4 & $\mathrm{Me}^{*}=15.5$ & $3-48$ \\
\hline $\begin{array}{l}\text { Local and lymph node } \\
\text { recurrence }\end{array}$ & 8 & 6.5 & 16.7 & 19.8 & $\mathrm{Me}^{*}=17.3$ & $5-44$ \\
\hline Distant metastases & 15 & 12.2 & 31.25 & 23.3 & $\mathrm{Me}^{*}=20$ & $3-60$ \\
\hline Total & 48 & 39 & 100 & - & - & - \\
\hline
\end{tabular}

* Me - median. 
The incidence of recurrences increased significantly with the increase of the $\mathrm{T}$ feature $(p=0.02), \mathrm{N}$ feature $(p=0.01)$, stage of clinical progression $(p=0.003)$, and histological malignancy grade $(p=0.002)$. The incidence of recurrences also depended on the origin of the cancer. In the glottic area recurrences were significantly less frequent than in the epiglottic area $(p=0.05)$ (Tab. 2).

No significant correlation was found between the type of recurrence (local or lymph node) and the clinicopathological tumour characteristics in the 5-year follow-up (Tab. 3).

Log-linear analysis did not reveal any simultaneous effect of several variables on the occurrence and type of recurrence. The 5 -year survival rate in the patients with recur- rence was significantly worse than in the patients without recurrence, $p<0.00001$. There was no statistically significant correlation between the type of recurrence and 5-year survival rate (Tab. 4).

Using multiple factor analysis based on Cox's regression model, the potential correlation between the 5-year survival rate in the patients with laryngeal cancer and the combination of the analyzed parameters was assessed. This analysis showed that among significant independent prognostic factors for the patients with laryngeal cancer during the 5-year follow-up were: status of the lymph nodes of the neck ( $\mathrm{N}$ feature) and stage of local progression ( $\mathrm{T}$ feature) $(p=0.00001)($ Tab. 5).

Table 2. Incidence of oncological treatment failures depending on clinicopathological factors in the group of patients included in the 5-year follow-up

\begin{tabular}{|c|c|c|c|c|}
\hline \multicolumn{2}{|l|}{$\begin{array}{l}\text { Clinicopathological } \\
\text { characteristics }\end{array}$} & \multicolumn{2}{|l|}{$\begin{array}{l}\text { Recurrence } \\
n=123\end{array}$} & \multirow[t]{2}{*}{ Significance level } \\
\hline & & \multirow{2}{*}{$\begin{array}{l}\text { None } \\
n=90(73.2 \%) \\
78(72.2 \%) \\
\end{array}$} & $\begin{array}{l}\text { Present } \\
n=33(26.8 \%)\end{array}$ & \\
\hline \multirow[t]{2}{*}{ Sex } & $M$ & & $30(27.8 \%)$ & \multirow{2}{*}{$\begin{array}{l}* \chi^{2}=0.11 \\
p=0.74\end{array}$} \\
\hline & $\mathrm{F}$ & $12(80 \%)$ & $3(20 \%)$ & \\
\hline \multirow[t]{2}{*}{ Age } & up to 60 years & $46(70.8 \%)$ & $19(29.2 \%)$ & \multirow{2}{*}{$\begin{array}{l}* \chi^{2}=0.4 \\
p=0.52\end{array}$} \\
\hline & over 60 years & $44(75.9 \%)$ & $14(24.1 \%)$ & \\
\hline \multirow[t]{2}{*}{ Smoking } & yes & $73(70.9 \%)$ & $30(29.1 \%)$ & \multirow{2}{*}{$\begin{array}{l}* \chi^{2}=0.47 \\
p=0.49\end{array}$} \\
\hline & no & $14(82.4 \%)$ & $3(17.6 \%)$ & \\
\hline \multirow[t]{3}{*}{ Alcohol } & no & $20(66.7 \%)$ & $10(33.3 \%)$ & \multirow{3}{*}{$\begin{array}{l}* \chi^{2}=1.68 \\
p=0.43 \\
\# \text { yes vs. no } \\
\left(\chi^{2}=0.68\right. \\
p=0.41)\end{array}$} \\
\hline & yes, rarely & $56(76.7 \%)$ & $17(23.3 \%)$ & \\
\hline & yes, at least once a week & $11(64.7 \%)$ & $6(35.3 \%)$ & \\
\hline \multirow[t]{3}{*}{ Location } & glottis & $49(81.7 \%)$ & $11(18.3 \%)$ & \multirow{3}{*}{$\begin{array}{l}* \chi^{2}=4.8 \\
\boldsymbol{p}=\mathbf{0 . 0 0 9} \\
\# \text { epiglottis vs. glottis } \\
\chi^{2}=3.74 \\
\boldsymbol{p}=\mathbf{0 . 0 5}\end{array}$} \\
\hline & epiglottis & $39(66.1 \%)$ & $20(33.9 \%)$ & \\
\hline & hypoglottis & $2(50 \%)$ & $2(50 \%)$ & \\
\hline \multirow[t]{4}{*}{$\mathrm{T}$ feature } & $\mathrm{T} 1$ & $23(95.8 \%)$ & $1(4.2 \%)$ & \multirow{4}{*}{$\begin{array}{l}* \chi^{2}=9.84 \\
\boldsymbol{p}=\mathbf{0 . 0 2} \\
\# \mathrm{~T} 1 \text { and } \mathrm{T} 2 \text { vs. T3 and T4 } \\
\left(\chi^{2}=5.24\right. \\
\boldsymbol{p}=\mathbf{0 . 0 2})\end{array}$} \\
\hline & $\mathrm{T} 2$ & $10(71.4 \%)$ & $4(28.6 \%)$ & \\
\hline & T3 & $33(73.3 \%)$ & $12(26.7 \%)$ & \\
\hline & $\mathrm{T} 4$ & $24(60 \%)$ & $16(40 \%)$ & \\
\hline \multirow[t]{4}{*}{$N$ feature } & No & $64(82.1 \%)$ & $14(17.9 \%)$ & \multirow{4}{*}{$\begin{array}{l}* \chi^{2}=11.25 \\
\boldsymbol{p}=\mathbf{0 . 0 1} \\
\# \text { N0 vs. N1, N2 and N3 } \\
\left(\chi^{2}=8.56\right. \\
\boldsymbol{p}=\mathbf{0 . 0 0 3})\end{array}$} \\
\hline & N1 & $17(58.6 \%)$ & $12(41.4 \%)$ & \\
\hline & N2 & $8(66.7 \%)$ & $4(33.3 \%)$ & \\
\hline & N3 & $1(25 \%)$ & $3(75 \%)$ & \\
\hline \multirow{4}{*}{$\begin{array}{l}\text { Stage of clinical progres- } \\
\text { sion }\end{array}$} & Stage I & $23(95.8 \%)$ & $1(4.2 \%)$ & \multirow{4}{*}{$\begin{array}{l}* \chi^{2}=13.82 \\
\boldsymbol{p}=\mathbf{0 . 0 0 3} \\
\# \text { stages I and II vs. stages III } \\
\text { and IV } \\
\left(\chi^{2}=4.34\right. \\
\boldsymbol{p}=\mathbf{0 . 0 4})\end{array}$} \\
\hline & Stage II & $8(66.7 \%)$ & $4(33.3 \%)$ & \\
\hline & Stage III & $23(85.2 \%)$ & $4(14.8 \%)$ & \\
\hline & Stage IV & $36(60 \%)$ & $24(40 \%)$ & \\
\hline \multirow[t]{3}{*}{ G } & G1 & $32(91.4 \%)$ & $3(8.6 \%)$ & \multirow{3}{*}{$\begin{array}{l}* \chi^{2}=8.31 \\
\boldsymbol{p}=\mathbf{0 . 0 0 2}\end{array}$} \\
\hline & G2 & $48(65.8 \%)$ & $25(34.2 \%)$ & \\
\hline & G3 & $10(66.7 \%)$ & $5(33.3 \%)$ & \\
\hline
\end{tabular}

* - level of statistical significance for the comparison of the incidence of failures between the various categories of a characteristic; \# - level of statistical significance for the comparison of the incidence of failures with the individual characteristics as described in this column. 


\begin{tabular}{|c|c|c|c|c|c|}
\hline \multicolumn{2}{|c|}{$\begin{array}{l}\text { Clinicopathological } \\
\text { characteristics }\end{array}$} & \multirow{3}{*}{\begin{tabular}{|l|}
$\begin{array}{l}\text { Local recurrence } \\
n=15(45.4 \%)\end{array}$ \\
$14(46.7 \%)$ \\
$1(33.3 \%)$
\end{tabular}} & \multirow{2}{*}{$\begin{array}{l}\text { Lymph node } \\
\text { recurrence } \\
n=10(30.3 \%) \\
8(26.7 \%) \\
\end{array}$} & \multirow{2}{*}{$\begin{array}{l}\begin{array}{l}\text { Local and lymph } \\
\text { node recurrence } \\
n=8(24.3 \%)\end{array} \\
8(26.7 \%) \\
\end{array}$} & \multirow{3}{*}{$\begin{array}{l}\text { Significance level } \\
\begin{array}{l}* \chi^{2}=2.35 \\
p=0.31\end{array}\end{array}$} \\
\hline Sex & $M$ & & & & \\
\hline & $\mathrm{F}$ & & $2(66.7 \%)$ & $0(0 \%)$ & \\
\hline \multirow[t]{2}{*}{ Age } & up to 60 years & $12(63.2 \%)$ & $5(26.3 \%)$ & $2(10.5 \%)$ & \multirow{2}{*}{$\begin{array}{l}* \chi^{2}=6.8 \\
\boldsymbol{p}=\mathbf{0 . 0 3}\end{array}$} \\
\hline & over 60 years & $3(21.4 \%)$ & $5(35.7 \%)$ & $6(42.9 \%)$ & \\
\hline \multirow[t]{2}{*}{ Smoking } & yes & $14(46.7 \%)$ & $8(26.7 \%)$ & $8(26.7 \%)$ & \multirow{2}{*}{$\begin{array}{l}* \chi^{2}=2.35 \\
p=0.31\end{array}$} \\
\hline & no & $1(33.3 \%)$ & $2(66.7 \%)$ & $0(0 \%)$ & \\
\hline \multirow[t]{3}{*}{ Alcohol } & no & $3(30 \%)$ & $3(30 \%)$ & $4(40 \%)$ & \multirow{3}{*}{$\begin{array}{l}* \chi^{2}=4.27 \\
p=0.37 \\
\# \text { yes vs. no } \\
\left(\chi^{2}=2.22\right. \\
p=0.33)\end{array}$} \\
\hline & yes, rarely & $9(52.9 \%)$ & $4(23.5 \%)$ & $4(23.5 \%)$ & \\
\hline & $\begin{array}{l}\text { yes, at least } \\
\text { once a week }\end{array}$ & $3(50 \%)$ & $3(50 \%)$ & $0(0 \%)$ & \\
\hline \multirow[t]{3}{*}{ Location } & glottis & $3(27.3 \%)$ & $3(27.3 \%)$ & $5(45.4 \%)$ & \multirow{3}{*}{$\begin{array}{l}* \chi^{2}=6.22 \\
p=0.18 \\
\# \text { epiglottis vs. glottis } \\
\left(\chi^{2}=3.56\right. \\
p=0.17)\end{array}$} \\
\hline & epiglottis & $10(50 \%)$ & $7(35 \%)$ & $3(15 \%)$ & \\
\hline & hypoglottis & $2(100 \%)$ & $0(0 \%)$ & $0(0 \%)$ & \\
\hline \multirow[t]{4}{*}{$\mathrm{T}$ feature } & T1 & $1(100 \%)$ & $0(0 \%)$ & $0(0 \%)$ & \multirow{4}{*}{$\begin{array}{l}* \chi^{2}=2.38 \\
p=0.88 \\
\# \text { T1 and T2 vs. T3 and T4 } \\
\left(\chi^{2}=0.27\right. \\
p=0.88)\end{array}$} \\
\hline & $\mathrm{T} 2$ & $1(25 \%)$ & $2(50 \%)$ & $1(25 \%)$ & \\
\hline & T3 & $5(41.7 \%)$ & $4(33.3 \%)$ & $3(25 \%)$ & \\
\hline & T4 & $8(50 \%)$ & $4(25 \%)$ & $4(25 \%)$ & \\
\hline \multirow[t]{4}{*}{$\mathrm{N}$ feature } & No & $5(35.7 \%)$ & $3(21.4 \%)$ & $6(42.9 \%)$ & \multirow{4}{*}{$\begin{array}{l}* \chi^{2}=10.24 ; p=0.11 \\
\# \mathrm{~N} 0 \text { vs. N1, N2 and N3 } \\
\left(\chi^{2}=4.62 ;\right. \\
p=0.1)\end{array}$} \\
\hline & N1 & $4(33.3 \%)$ & $6(50 \%)$ & $2(16.7 \%)$ & \\
\hline & N2 & $3(75 \%)$ & $1(25 \%)$ & $0(0 \%)$ & \\
\hline & N3 & $3(100 \%)$ & $0(0 \%)$ & $0(0 \%)$ & \\
\hline \multirow{4}{*}{$\begin{array}{l}\text { Stage of clinical } \\
\text { progression }\end{array}$} & \begin{tabular}{|l|} 
Stage I \\
\end{tabular} & $1(100 \%)$ & $0(0 \%)$ & $0(0 \%)$ & \multirow{4}{*}{$\begin{array}{l}* \chi^{2}=4.59 \\
p=0.6 \\
\text { \# stages I and II vs. } \\
\text { stages III and IV } \\
\left(\chi^{2}=0.27\right. \\
p=0.88)\end{array}$} \\
\hline & Stage II & $1(25 \%)$ & $2(50 \%)$ & $1(25 \%)$ & \\
\hline & Stage III & $2(50 \%)$ & $0(0 \%)$ & $2(50 \%)$ & \\
\hline & Stage IV & $11(45.8 \%)$ & $8(33.3 \%)$ & $5(20.8 \%)$ & \\
\hline \multirow[t]{3}{*}{ G } & G1 & $1(33.3 \%)$ & $1(33.3 \%)$ & $1(33.3 \%)$ & \multirow{3}{*}{$\begin{array}{l}* \chi^{2}=1.17 \\
p=0.88\end{array}$} \\
\hline & G2 & $12(48 \%)$ & $8(32 \%)$ & $5(20 \%)$ & \\
\hline & G3 & $2(40 \%)$ & $1(20 \%)$ & $2(40 \%)$ & \\
\hline
\end{tabular}

* - level of statistical significance for the comparison of the incidence of failures between the various categories of a characteristic; \# - level of statistical significance for the comparison of the incidence of failures with the individual characteristics as described in this column.

Table 4. Survival rate during the 5-year follow-up depending on the occurrence and type of recurrence, taking into account only tumour as the cause of death

\begin{tabular}{|c|c|c|c|c|c|}
\hline \multirow{2}{*}{\multicolumn{2}{|c|}{ Feature }} & \multirow[t]{2}{*}{ Total } & \multicolumn{2}{|c|}{ 5-year survival rate } & \multirow[t]{2}{*}{ Significance level during the 5 year follow-up } \\
\hline & & & $\bar{n}$ & $(\%)$ & \\
\hline \multirow[t]{2}{*}{ Recurrence } & present & 32 & 7 & 21.9 & \multirow[t]{2}{*}{$p<0.00001$} \\
\hline & not present & 74 & 65 & 87.8 & \\
\hline \multirow[t]{3}{*}{ Type of recurrence } & local & 15 & 4 & 26.7 & \multirow[t]{3}{*}{$p=0.16$} \\
\hline & lymph node & 9 & 2 & 22.2 & \\
\hline & local + lymph node & 8 & 1 & 12.5 & \\
\hline
\end{tabular}

\section{Table 5. Multiple factor analysis (using Cox's model) of the 5-year follow-up}

5-year follow-up

\begin{tabular}{|l|l|l|l|}
\hline \multirow{4}{*}{$N$} & 0 & 1 & \multirow{2}{*}{$\mathbf{0 . 0 1}$} \\
\cline { 2 - 3 } & 1 & $1.79(1.15-2.78)$ \\
\cline { 2 - 3 } & 2 & $3.19(1.32-7.74)$ & \\
\cline { 2 - 3 } & 3 & $5.71(1.51-21.52)$ & \multirow{2}{*}{0.02} \\
\hline \multirow{4}{*}{} & 1 & 1 & \\
\cline { 2 - 3 } & 2 & $1.56(1.08-2.24)$ & \\
\cline { 2 - 3 } & 3 & $2.42(1.17-5.0)$ & \\
\cline { 2 - 3 } & 4 & $3.77(1.27-11.18)$ & \\
\end{tabular}




\section{Discussion}

Numerous reports of the results of treatment of earlystage laryngeal cancer suggest the similar effectiveness of surgical interventions and radiation therapy.

In 1993, Steiner reported the results of endoscopic laser resection of laryngeal tumours at local progression stages $T_{\text {is }}$ $\mathrm{T} 1$ and T2 in 240 patients. The 5-year survival rate, regardless of the cause of death, was $86.5 \%$. Taking into account only the tumour as the cause of death, the observed 5-year survival rate was $100 \%$ [7]. Betlejewski et al. [8], in a group of 93 patients with laryngeal cancer at progression stages T1 and T2, observed recurrences in $13(13.9 \%)$ patients in the period between 2 months and 3 years after surgery. Semczuk et al. reported a 5 -year survival rate of $78 \%$ in patients after partial laryngectomy, as determined in four laryngology clinics in the period 1976-1979 [9]. Similar results were reported by other authors [10, 11].

Compared to partial laryngectomy with external access, the advantage of endoscopic laser treatment of early-stage (T1 and T2) laryngeal cancer is the preservation of the larynx, no need for tracheotomy, considerably shorter hospitalization and earlier return to everyday life, the possibility of repeated microsurgery, and lack of complications in wound healing.

Numerous authors have published the results of combined treatment of advanced (T3-T4) laryngeal cancer with poorer outcome compared to surgical treatment only [12, 13]. The results of combined therapy of laryngeal cancer in the authors' own study were similar, in which a 5-year survival rate of $42.6 \%$ was obtained, as opposed to $78.2 \%$ in patients treated only surgically in a report from four laryngology clinics [9], in which the 5-year survival rate after combined therapy was $46 \%$, while that after surgical treatment only was $61 \%$. Apparently, the poorer outcome of combined therapy compared to surgical treatment alone is a result of the higher stage of clinical and local progression and the presence of lymph node metastases in patients treated with the former method. In the analysis of correlations between the stage of local progression ( $T$ feature), status of regional lymph nodes ( $\mathrm{N}$ feature) and survival rate in the investigated patients, a statistically significant correlation between these characteristics was established. It was found that the majority of patients with N0 feature survived the 5 -year follow-up. Survival rate decreased with the increase of the stage of local progression $(\mathrm{T})$.

Multiple factor analysis of the obtained results demonstrated that recurrence is not an independent prognostic factor for the 5-year survival rate.

In the investigated group in the 5-year follow-up, a statistically significant correlation was found between recurrences and the stage of local progression $(T)$, status of regional lymph nodes $(\mathrm{N})$, stage of clinical progression and histological malignancy stage (G). No statistically significant correlation was established between the type of recurrence and clinicopathological characteristics. Similar results were reported by Spector et al. [14].

The effectiveness of surgical treatment should be based on the most effective possible minimization of local recurrences and the concurrent increase in patient survival rate. In patients with advanced laryngeal cancer treated surgically, there is a risk of local and/or regional recurrence. The risk of recurrence after surgical treatment is high in patients after microscopically or macroscopically non-radical resection of the primary or metastatic tumour. This applies to tumours at both late stages of clinical progression and a low grade of histological malignancy, especially in patients with the tumour infiltrating the epiglottis, as well as patients with the tumour in the hypoglottic region. Treating recurrences of laryngeal cancer poses a much greater problem than primary treatment.

One of the main reasons for failures in the treatment of laryngeal cancer are metastases to regional lymph nodes. The outcome depends both on the success of treatment of the primary tumour and the procedure used to treat metastases to lymph nodes.

The percentage of patients treated surgically due to recurrences in regional lymph nodes varies from $3 \%$ to $20 \%$, and the time of occurrence of cancer metastases is from 1 month to 7 years. Most metastases occur within 1 year, but some authors emphasize that approx. $28 \%$ of cases occurred 3-5 years after the end of treatment [15]. The incidence of lymph node recurrences increases in the case of non-radical surgery, macroscopically and microscopically identified metastases to lymph nodes, or cancer infiltration of tissues outside the lymph node capsule. Particularly poor prognosis is related with recurrences that occurred a short time after surgery [16-18].

Distant metastases in the investigated group occurred in $12.2 \%$ of the patients included in the 5 -year follow-up, with the mean time of occurrence of metastases of 23.3 months. Similar results, from several to a dozen per cent, were obtained by other authors $[12,19,20]$. The incidence of distant metastases depended on the stage of local progression and the presence of local and/or regional recurrences [19].

\section{Conclusions}

Recurrences most often occur in patients with an epiglottic tumour at stages T3 and T4 of local progression, patients with metastases to lymph nodes, patients at stages III and IV of clinical progression, and patients with poorly differentiated squamous cell carcinoma (G3). Patients with local recurrences have a significantly worse prognosis than those without recurrences. The presence of recurrences is an important independent prognostic factor.

Source of funding: This work was funded by project no. 3 PO5C 06224.

Conflict of interest: The authors declare no conflict of interests.

\section{References}

1. Bień S, Kaminski B, Żyłka S, et al. Ewolucja obrazu epidemiologicznego i klinicznego raka krtani i krtaniowej części gardła w Polsce w latach 1991-2001. Otolar Pol 2005; 59(2): 169-181.

2. Kaufman JA, Burke AJ. The etiology and pathogenesis of laryngeal carcinoma. Otolaryngol Clin North Am 1997; 30(8): 11-19.

3. Schottenfeld D, Fraumeni J. Cancer epidemiology and prevention. New York: Oxford University Press; 1996.

4. Krecicki T, Smigiel R, Fraczek M, et al. Studies of the cell cycle regulatory proteins P16, cyclin D1 and retinoblastoma protein in laryngeal carcinoma tissue. J Laryngol Otol 2004; 118(9): 676-680.

5. Spissel B, Beahhrs OH, Hermanek P, et al. Atlas TNM. Warszawa: SanMedica; 1994.

6. Shanmugaratnam K, Sobin LH. Histological typing of tumours of the upper respiratory tract and ear. Berlin, Heidelberg: Springer-Verlag; 1991. 
7. Steiner W. Results of curative laser microsurgery of laryngeal carcinomas. Am J Otolaryngol 1993; 14(2): 116-121.

8. Betlejewski S, Sinkiewicz A, Dalke K, et al. Reoperacje z powodu wznowy miejscowej raka krtani po chordektomii laserowej. Otolaryng Pol 1999; Supl. 30: 173-175.

9. Semczuk B, Szmeja Z, Janczewski G, et al. Wydolność operacyjnego leczenia chorych na raka krtani w czterech ośrodkach klinicznych. Otolar Pol 1995; 49(3): 195-200.

10. Bocca E. Surgical management of supraglottic cancer and its lymph node metastasis - a conservative perspective. Ann Otol Rhinol Laryngol 1991; 100(4 Pt. 1): 261-267.

11. Szmeja Z, Kruk-Zagajewska A, Kulczyński B, et al. Wyniki operacyjnego leczenia raka krtani w Klinice Otolaryngologicznej AM w Poznaniu w latach 1945-1985. Otolar Pol 1987; 41(1): 100-110.

12. Sas-Korczyńska B, Korzeniowski S, Skołyszewski J. Wyniki leczenia skojarzonego: całkowitego wycięcia krtani z następową radioterapią u chorych na zaawansowanego raka krtani. Otolar Pol 1997; Supl. 28: 203-204.

13. Składowski K, Przeorek W, Mucha A, et al. Ocena wyników skojarzonego leczenia raka krtani w materiale klinicznym Instytutu Onkologii w Gliwicach w latach 1987-1996. Otolar Pol 2000; 54(Supl. 31): 37-39.

14. Spector JG, Sessions DG, Haughey BH, et al. Delayed regional metastases, distant metastases, and second primary malignancies in squamous cell carcinomas of the larynx and hypopharynx. Laryngoscope 2001; 111(6): 1079-1087.

15. van der Brekel MWH, Castelijns JA. Lymph node staging in patients with clinically negative neck examinations by ultrasoundguided aspiration cytology. Am J Surg 1991; 162(4): 362-365.

16. Betlejewski S, Sinkiewicz A. Ocena czynnościowa głosu po chordektomii laserowej. Otolar Pol 1994; Supl. 16: $303-305$.

17. Bolot G, Pouparet M, Zrounba P, et al. Laser treatment for glottic carcinoma. XVI World Congress of Otorhinolaryngology Head and Neck Surgery. Sydney; 1997.

18. Ribári O, Hirsberg A, Szabó G, et al. Laser surgery of the vocal cord. Acta Otolaryngol Suppl 1997; 527: 74-76.

19. Jäckel MC, Rausch H. Distant metastasis of squamous epithelial carcinomas of the upper aerodigestive tract. The effect of clinical tumor parameters and course of illness. HNO 1999; 47(1): 38-44.

20. Maier H, Dietz A, Gewelka U, et al. Tobacco and alcohol and the risk of head and cancer. Clin Investig 1992; 70(3-4): $320-327$.

Address for correspondence:

Agata Barbara Smoleń, MD, PhD, Assoc. Prof.

Katedra i Zakład Epidemiologii i Metodologii Badań Klinicznych UM

ul. Chodźki 1

20-093 Lublin

Polska

Tel.: +48 81 448-63-70

E-mail: agata.smolen@umlub.pl

Received: 25.04.2016

Revised: 23.06.2016

Accepted: 23.06.2016 